\title{
Autoimmune polyglandular syndrome type 3 variant in rheumatoid arthritis
}

\author{
TARO HORINO $^{1}$, MASAMI OGASAWARA $^{1}$, OSAMU ICHII $^{2}$, YOSHIO TERADA $^{1}$ \\ ${ }^{1}$ Department of Endocrinology, Metabolism and Nephrology, Kochi Medical School, Kochi University, \\ Kohasu, Oko-cho, Nankoku, Kochi 783-8505, Japan \\ ${ }^{2}$ Laboratory of Anatomy, Basic Veterinary Sciences, Faculty of Veterinary Medicine, Hokkaido University, \\ Kita 18, Nishi 9, Kita-Ku, Sapporo, 060-0818, Japan
}

\begin{abstract}
Introduction. Although type 1 diabetes mellitus is largely associated with autoimmune thyroid disease and this entity has been recently referred to as autoimmune polyglandular syndrome type 3 variant, the autoimmune polyglandular syndrome type 3 variant in patients with rheumatoid arthritis has not been reported so far. We herein describe the first case of rheumatoid arthritis that was associated with autoimmune polyglandular syndrome type 3 variant.

Case report. A 77-year-old woman with a 15-year history of rheumatoid arthritis (RA) and a 10 -year history of type 2 diabetes mellitus (T2D) presented with polyarthralgia and hyperglycaemia Methotrexate $16 \mathrm{mg} /$ week had been started from the onset and was continued, and adalimumab $40 \mathrm{mg}$ /day was started for RA. Insulin treatment was also started for the diabetes. Laboratory examinations revealed high levels of C-reactive protein (CRP), rheumatoid factor, anti-cyclic citrullinated peptide antibody, and matrix metalloprotease 3. She was admitted multiple times as the symptoms recurred after treatment. Subsequently, based on the clinical course and investigations, she was diagnosed with type 1 diabetes mellitus and Graves' disease occurring during the course of RA and T2D. Her clinical course improved after reinforcement of insulin therapy and the addition of thiamazole therapy.

Conclusion. In patients with rheumatoid arthritis, the autoimmune polyglandular syndrome type 3 variant should be considered as the cause of the deterioration.
\end{abstract}

Key words: autoimmune thyroid disease (AITD), autoimmune polyglandular syndrome type 3 variant (APS3v), Graves' disease (GD), rheumatoid arthritis (RA), type 1 diabetes mellitus (T1D), type 2 diabetes mellitus (T2D).

\section{INTRODUCTION}

Autoimmune polyglandular syndrome (APS), which affects multiple endocrine and non-endocrine organs $[1,2]$, is classified into three major subtypes: APS type 1, a rare autosomal recessive disorder that manifests in childhood with the triad of mucocutaneous candidiasis, hypoparathyroidism, and autoimmune Addison's disease; APS type 2 that presents in middle age with the combination of autoimmune Addison's disease and autoimmune thyroid disease (AITD) and/or type 1 diabetes (T1D); and APS type 3 , defined as the combination of AITD with other autoimmune diseases, except for Addison's disease and hypoparathyroidism. AITD with T1D is considered as a variation of type 3 APS, which is known as variant type 3 APS (APS3v) [3]. Herein, we present the clinical course of APS3v in a patient.

\section{CASE REPORT}

A 77-year-old woman with a 15 -year history of rheumatoid arthritis (RA) and a 10-year history of type 2 diabetes mellitus (T2D) presented with polyarthralgia and hyperglycaemia. Before admission, she had experienced poor glycaemic control owing to inadequate diet control and severe inflammatory response under steroid therapy (prednisolone $5 \mathrm{mg} /$ day). She had been undergoing intensive subcutaneous insulin therapy with a regimen of insulin glargine and insulin aspart. Physical examination revealed a body weight of $57.9 \mathrm{~kg}$ (body mass index, $27.3 \mathrm{~kg} / \mathrm{m}^{2}$ ) and polyarthralgia in the shoulders, elbows, wrists, hands, hip joints, knees, ankle joints, and feet. Laboratory examinations revealed that $\mathrm{C}$-reactive protein (CRP), rheumatoid factor, anti-cyclic citrullinated peptide antibody, and matrix metalloprotease 3 levels were 9.3 (reference range $<0.15) \mathrm{mg} / \mathrm{dL}, 1118.8(<15) \mathrm{IU} / \mathrm{mL}, 20.1(<4.5) \mathrm{U} / \mathrm{mL}$, and $179.9(17.3-59.7) \mathrm{ng} / \mathrm{mL}$, respectively. Serological tests, including those for antinuclear antibodies and anti-ds-DNA, anti-Sm, SS-A, SS-B, and anti-RNP antibodies were negative. Plasma glucose and $\mathrm{HbA} 1 \mathrm{c}$ levels were $170 \mathrm{mg} / \mathrm{dL}$ and $12.4 \%$, respectively. As shown in Figure 1, methotrexate $16 \mathrm{mg} /$ week started at onset was continued, and 
adalimumab $40 \mathrm{mg} /$ day was started for RA. Insulin therapy was started for the diabetes. CRP and arthralgia improved, and she was discharged. However, she was readmitted following liver dysfunction. Methotrexate-induced liver damage was suspected. During the second admission, methotrexate was tapered to $12 \mathrm{mg} /$ week, and liver function normalized without relapse. Two months after discharge, arthralgia recurred following the elevation of $\mathrm{HbAlc}$ levels. During the third admission, the blood glucose level was controlled via diet and insulin therapy, resulting in the remission of arthralgia. Concurrently, anti-glutamic acid decarboxylase antibody (GAD antibody) level was $<0.3 \mathrm{U} / \mathrm{mL}(<5.0)$. TSH, free $\mathrm{T} 4, \mathrm{ACTH}$, and cortisol levels were within normal limits. Insulin and C-peptide immunoreactivity (CPR) levels were 39.37 and 1.58 , respectively. Subsequently, polyarthralgia did not recur; however, HbA1c level increased gradually. The patient was admitted for four more times $\left(4^{\text {th }}\right.$ to $7^{\text {th }}$ admission) for investigation and treatment of the deterioration of blood glucose control. On her 5th admission, she tested positive for GAD antibody at $14.9 \mathrm{U} / \mathrm{mL}$, and on her $7^{\text {th }}$ admission, she tested positive for TRAb at $4.49 \mathrm{IU} / \mathrm{L}(<2.0)$. TSH level decreased to $<0.005 \mu \mathrm{IU} / \mathrm{mL}(0.38-4.30)$. Free T3 and free T4 levels increased to 4.68 (2.4-4.0) $\mathrm{pg} / \mathrm{mL}$ and $2.91 \quad(0.94-1.60) \mathrm{ng} / \mathrm{dL}$, respectively. ACTH and cortisol levels were 48.5 (7.2-63.3) $\mathrm{pg} / \mathrm{mL}$ and $19.9(4.5-21.1) \mu \mathrm{g} / \mathrm{dL}$, respectively. Thyroid ultrasonography showed no abnormal findings in the thyroid. Magnetic resonance imaging did not show ophthalmopathy. Bone density was measured using dual energy X-ray absorptiometry and showed that she had an average bone density according to age. Based on the above clinical course and data, the patient was diagnosed with T1D and Graves' disease (GD) occurring during the course of RA and T2D. Her clinical course improved following the reinforcement of insulin therapy and the addition of thiamazole therapy.

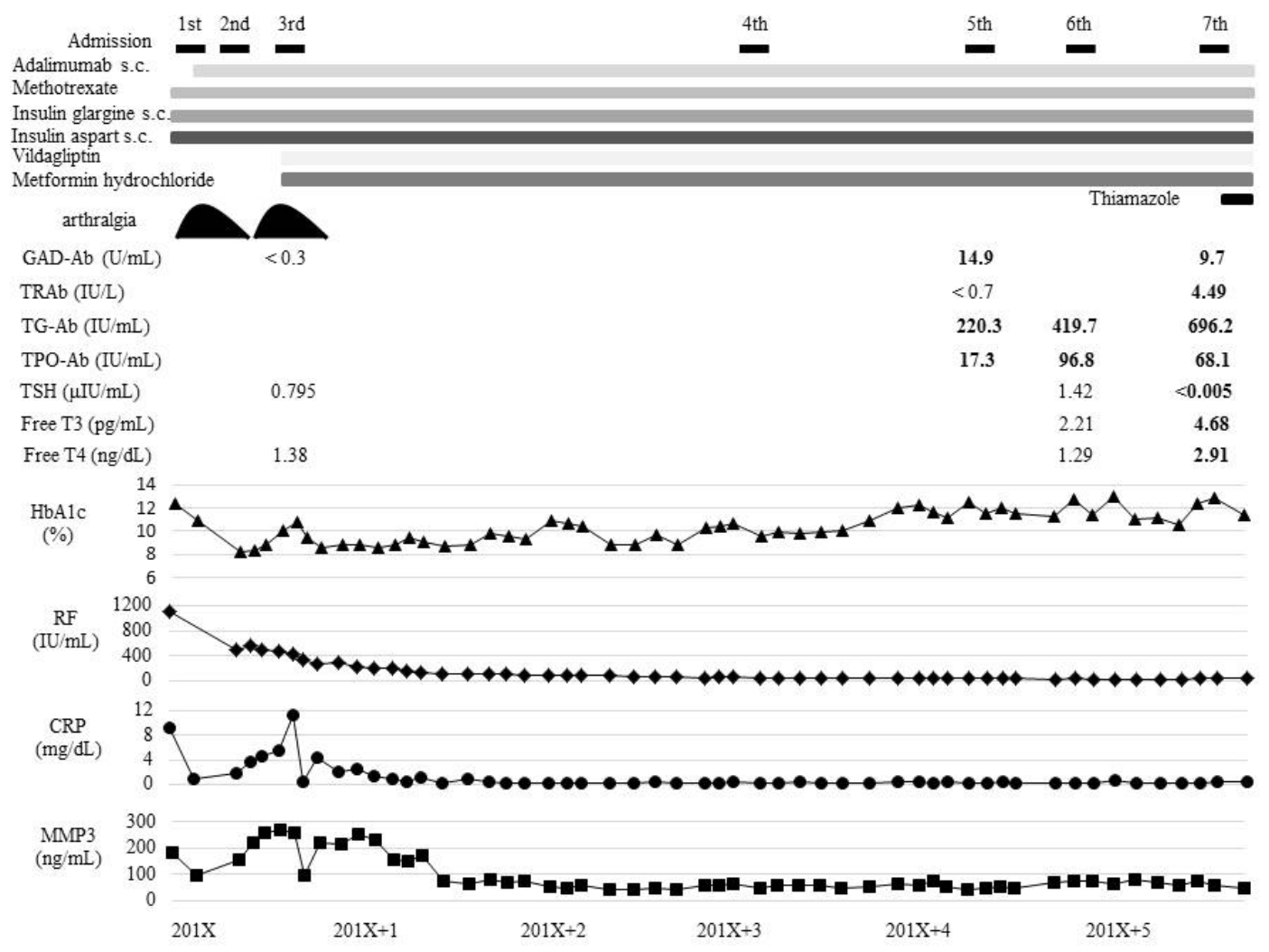

Figure 1. Clinical course of the patient.

\section{DISCUSSION}

APS3v is defined as the occurrence of T1D and autoimmune thyroid disease (AITD), both of which are common autoimmune endocrine diseases [4]. Studies reported that $20-30 \%$ of children, adolescents, and young adults with T1D were positive for thyroid antibodies [4]. Conversely, $8-10 \%$ of children, adolescents, and young adults with AITD (GD and/or Hashimoto's thyroiditis) have been reported to have islet cell antibodies [4]. To the best of our knowledge, this is the first report 
of APS3v in RA. RA is the most common autoimmune disease. Furthermore, diabetes mellitus (DM) is also a typical autoimmune disease with a growing number of patients and a high global prevalence. Therefore, in patients with RA and $\mathrm{DM}$, blood glucose management is important to improve mortality $[5,6]$. As blood glucose control deteriorates in the presence of inflammation, such as in RA, the vicious circle of inflammation and hyperglycaemia induces mutual deterioration. In our case, glycaemic control improved initially as inflammation improved. However, although we could control RA-related inflammation for a long time, blood glucose control gradually deteriorated, and T1D was considered as the patient tested positive for GAD antibody. In addition, although insulin treatment was strengthened thereafter, deterioration of blood glucose control and weight loss progressed. Moreover, positive TRAb test and hyperthyroidism were noted, and it was considered that GD had developed.

Conversely, our patient tested positive for autoantibodies against pancreatic islet antigen. In recent years, cases with type 2 diabetes and autoantibodies against pancreatic islet antigen are defined as latent autoimmune diabetes in adults (LADA) or slowly progressive type 1 diabetes [7]. It has also been reported that type 1 and type 2 may be at the opposite ends of the same pathology [7]. Our case may be representative of the clinical course of LADA, and thus, may be useful for assessing the pathology of LADA.

In conclusion, we report a case of a patient with APS3v who developed T1D and GD during the clinical course of RA. In our case, it was possible to observe the long-term course of APS3v development in RA. RA, T1D, and GD are autoimmune diseases, which are encountered frequently, and thus, might coexist more frequently than is currently known. In inflammatory autoimmune diseases, such as RA, clinicians should first attempt to control the inflammation in the presence of blood glucose control. Subsequently, when deterioration of glycaemic control is observed, the presence of coexisting diseases, such as APS3v, as the cause of the deterioration must be investigated.

Introducere. Deși diabetul zaharat de tip 1 este asociat cu tiroidită autoimună (sindrom poliendocrin autoimun de tip 3), până acum nu au fost prezentate cazuri ce asociau și artrita reumatoidă. Este prezentat primul caz de pacient cu poliartrită reumatoidă şi sindrom poliendocrin autoimun de tip 3 .

Prezentare de caz. O pacientă în vârstă de 77 de ani cu istoric de 15 ani de artrită reumatoidă și de 10 ani de diabet zaharat tip 2 se prezintă cu poliartalgii și hiperglicemie. S-a inițiat tratamentul cu adalimumab $40 \mathrm{mg} / z i$ precum și cu insulină. Analizele de laborator au relevat niveluri crescute ale proteinei $C$ reactive, ale factorului reumatoid, ale matrix metaloproteinazei 3 şi ale anticorpilor ciclici citrulinați. Pacienta a fost internată de mai multe ori pentru că a avut numeroase recăderi. Aceasta a fost diagnosticată cu diabet zaharat tip 1 şi boală Graves. Simptomatologia s-a îmbunătățit odată cu tratamentul cu insulină și tiamazol.

Concluzii. La pacienții cu artrită reumatoidă sindromul poliglandular autoimun tip 3 ar putea fi luat în considerare atunci când starea pacientului se deteriorează.

Correspondence to: Taro Horino, M.D., Ph.D. Department of Endocrinology, Metabolism and Nephrology, Kochi Medical School, Kohasu, Oko-cho, Nankoku, Kochi 783-8505, Japan

Tel: +81-88-880-2343, fax: +81-88-880-2344

E-mail: horinott@yahoo.co.jp

Grant support: None.

Acknowledgements: None.

Patient privacy: Informed consent was obtained from the patient described in the present study.

Conflict of interest disclosure: The authors declare that there are no conflicts of interest. 


\section{REFERENCES}

1. MICHELS AW., GOTTLIEB PA. Autoimmune polyglandular syndromes. Nat Rev Endocrinol. 2010; 6(5):270-7.

2. KAHALY GJ., FROMMER L. Polyglandular autoimmune syndromes. J Endocrinol Invest. 2018; 41(1):91-98.

3. HUBER A., MENCONI F., CORATHERS S., JACOBSON EM., TOMER Y. Joint genetic susceptibility to type 1 diabetes and autoimmune thyroiditis: from epidemiology to mechanisms. Endocr Rev. 2008; 29(6):697-725.

4. GRUBIC Z., ROJNIC PUTAREK N., MASKALAN M., ZUNEC R., STINGL JANKOVIC K., BUREK KAMENARIC M., et al. Human Leukocyte Antigen class II polymorphisms among Croatian patients with type 1 diabetes and autoimmune polyglandular syndrome type 3 variant. Gene. 2018; 674:93-97.

5. D'ANTONA L., et al. Prevalence of undiagnosed diabetes in rheumatoid arthritis: an OGTT Study. Medicine (Baltimore). 2016; 95(7): 2552.

6. DOUGADOS M., SOUBRIER M., ANTUNEZ A., BALINT P., BALSA A., BUCH MH., et al. Prevalence of comorbidities in rheumatoid arthritis and evaluation of their monitoring: results of an international, cross-sectional study (COMORA). Ann Rheum Dis. 2014; 73(1):62-8.

7. NAIK RG., BROOKS-WORRELL BM., PALMER JP. Latent autoimmune diabetes in adults. J Clin Endocrinol Metab. 2009; 94(12):4635-44.

Received March $11^{\text {th }} 2019$ 